\title{
Om de politiske Porhold paa Als 1848.
}

Af et Brev fra K. Knudsen, Lysholm, til Broderen Christian.

Meddelt af Nis Nissen, Nørborg.

Lysholm, den 17. April 1848.

Da Madam Hansens Broder paa Bommerlund imorgen rejser til Fyn, saa vilde jeg gjerne benytte Lejligheden og sende Dig et Par Ord, men hvad skal jeg da meddele Dig, hvor skal jeg begynde og hvor ende? Fast glemmer man $i$ denne uheldsvangre Tid sine egne private Anliggender for det Offentlige. Store Omvæltninger ville skee, det er vist. Herren vende det da til det bedste! Fremfor alt ville vi bede ham staa Konge og Fædreland bi i Farens Stund, skjænke Kongen og hans Raad saavelsom Folket Kraft og Mod til at forsvare sig imod fremmed Vold og Magt og til at revse Forræderi og Oprør. Danmark har i mange Aar maattet vige tilbage og lade sig foreskrive haarde Betingelser af sine overmægtige Naboer. Vi ville haabe at Gjengjældelsens Dag er kommen og at vi ville faa Oprejsning for det lidte. En folkelig og kraftig Konge sidder paa Tronen; kraftige ansvarlige Ministre staa ved hans Side. Dette er en god Ting. Held og Velsignelse over Danmark!!

Jeg kan vel sagtens ikke fortælle Dig noget nyt herfra, thi Aviserne indeholder fast alt, imidlertid vil jeg dog gaa Begivenhederne her paa Als flygtig 
igjennem. Søndagen den 26. Marts kom her Efterretning om den provisoriske Regjering. Efterretningen var fra denne sendt til Embedsmændene (de tysksindede) om at den anerkjendte dem $i$ deres Embeder samt Befaling til dem om ufortøvet at sende deres Kassebeholdning ind til Flensborg.

Imidlertid vare Bønderne i Mjels kommen paa Benene, og Riegels,") Fægteborg gjorde meget for at høre, hvorledes Stemningen var paa Landet, som naturligvis var dansk med yderst faa Undtagelser. En Forsamling blev afholdt paa Mjelsgaard om Mandagen hvortil hele Nørborgs Øvrighed var indbuden eller rettere sagt af Bønderne tvungen til at møde. Riegels og Bønderne talte der og stemte for en kraftig Optræden mod Tyskheden. Tirsdag blev bestemt til en ny Sammenkomst for hele Nørreherred. Amtmanden og de andre blev da givet at forstaa af Bønderne i Mjels, at de maatte vise dem lidt mere enthusiastiske for den danske Sag som Kongens Embedsmænd, hvilket de da ogsaa gjorde.

I Sønderborg var der om Søndagen Forsamling paa Raadhuset, hvor man drøftede om den provisoriske Regjering skulde anerkjendes.

Tyskerne med Borgmesteren i Spidsen vare meget højrøstede, de Danske med Hansen-Norsk ikke mindre og Mødet blev udsat til Mandag. Heller ingen Resultat denne Dag. Tirsdag skulde det afgjøres hvilket Parti de skulde slaa dem til, men om Morgenen lod en kongelig Korvet sig se i Havnen, og alle vare naturligvis da Danske paa eengang. Havde dette Skib ei kommet den Dag og havde de erklæret

*) Husfoged, Stamfader til Slægten Riegels i Kongeriget. 
sig for den provisoriske Regjering, saa havde de vistnok havt alle Bønderne fra Landet paa Halsen. De havde lovet Sonderborgerne, at deres Blod i saa Fald skulde have flydt i Rendestenen. Paa Augustenborg indfandt de Sønderherreds Bønder sig straks efter, tvang de tyske Augustenborgere til at være danske, hængte Dannebrog op i Slotstaarnet, aabnede Slottet, som blev bevogtet af Hertugens Jægere, opbrød Rustkamret og borttog de derværende Geværer. Hele Als er Dansk (De saa hurtig omvendte ere indvortes Tyskere endnu) -

En Folkevæbning dannede sig straks baade her og i Sønderherred. For os er Riegels Anfører. Vi udgjør i det Hele 1500 Mand, dels med Geværer, dels med Spyd. I Sønderherred er Leutnant Ronncker Anfører. Der er vel 2000 Mand saa godt. Der øves flittig. Kongen, som var her et Par Dage, inspicerede vort Korps for otte Dage siden. Vi vare opstillede i det Hartspringske Hulkoppel og gjorde flere Evolutioner for ham. Han var tilfreds dermed. Derfra tog han til Maibølgaard for at se Sønderherreds Bevæbning. Han saa meget bleg ud, men er forresten en smuk Mand.

Heuermann og Petersen fra Amtsstuen i Norborg sidder fast i Sønderborg. Pastor Petersen i Notmark, Pastor Schlaikjer i Asserballe og Pastor Gemer paa Augustenborg ere suspenderede. Augustenborg er lagt til Ketting Kirke og Kapellan Fangel er konstitueret Præst i Notmark og Asserballe. Borgmesteren i Sønderborg og Steffens i Nørborg er ligeledes suspenderede og Advokat Ravn i Sønderborg og Advokat Johansen er kommen til Nørborg for at fungere indtil videre, den forste som Borgmester, 
den siclste som Herredsfoged. Der var stærkt Bud efter Pastor Ahlmann i Svenstrup, men Biskoppen*) gik i Forbøn for ham. Dette gjorde han ogsaa for de andre Præster, men Beslutningen om disses Afskedigelse var allerede underskreven af Kongen.

Palæet og Slottet paa Augustenborg er indrettet til Lazaretter. Jeg var der forleden Dag med en Del Linned, jeg havde indsamlet her paa Egnen til de Saarede og Kvæstede. Alle Meubler, etc. hvad der var i Værelserne, er henpakket i Kirken.

Jeg var rundt ved alle de Syge, der var i Slottet. De ligger her ret fiint i Varelser med Atlaskes og Damaskes Betræk. Der ligger for Øjeblikket ca. 180, deriblandt nogle Tyske. For Øjeblikket veed jeg ikke, hvorledes det staar med vor Hær. Hidtii er den gaaet godt frem, og maaske kan der forhandles. Ved Dybbølbjerg opkastes i disse Dage Skandser, maaske for Forsigtigheds Skyld. Jeg kunde skrive Dig mange Blade fulde, men nu nok for denne

Gang. - - -

*) Tetens. 